\title{
Regulation of Intracellular pH in the Rabbit Cortical Collecting Tubule
}

I. David Weiner and L. Lee Hamm

Renal Division, Department of Medicine, Washington University School of Medicine, St. Louis, Missouri 63110

\begin{abstract}
The cortical collecting tubule (CCT) is an important nephron segment for $\mathrm{Na}^{+}, \mathrm{K}^{+}$, water and acid-base transport. Differential loading characteristics of the pH sensitive dye $\mathbf{2}^{\prime}, \mathbf{7}^{\prime}$-bis-(2carboxyethyl)-5(and-6)carboxyfluorescein (BCECF) and basolateral $\mathrm{Cl}^{-}$removal were used to identify and study intracellular $\mathrm{pH}\left(\mathrm{pH}_{\mathrm{i}}\right)$ regulation in each of three cell types involved in this transport. Both principal cells and $\beta$-intercalated cells were found to have a basolateral $\mathrm{Na}^{+} / \mathrm{H}^{+}$exchanger based on the $\mathrm{Na}^{+}$and amiloride sensitivity of $\mathrm{pH}_{\mathbf{i}}$ recovery from acid loads.

Intercalated cells demonstrated abrupt $\mathrm{pH}_{\mathrm{i}}$ changes with basolateral $\mathrm{Cl}^{-}$removal. $\alpha$-intercalated cells alkalinized; $\beta$-intercalated cells acidified. In the $\beta$-intercalated cells, luminal $\mathrm{Cl}^{-}$removal blocked changes in $\mathrm{pH}_{\mathrm{i}}$ in response to changes in luminal $\mathrm{HCO}_{3}^{-}$or peritubular $\mathrm{Cl}^{-}$, providing direct evidence for a luminal $\mathrm{Cl}^{-} / \mathrm{HCO}_{3}^{-}$exchanger. In principal cells, brief removal of either peritubular or luminal $\mathrm{Cl}^{-}$resulted in no change in $\mathrm{pH}_{i}$; however, return of peritubular $\mathrm{Cl}^{-}$after prolonged removal resulted in a rapid fall in $\mathrm{pH}_{1}$ consistent with a basolateral $\mathrm{Cl}^{-} / \mathrm{HCO}_{3}^{-}$exchanger, which may be relatively inactive under baseline conditions. Therefore, $\mathrm{Cl}^{-} / \mathrm{HCO}_{3}^{-}$exchange is present in all three cell types but varies in location and activity. (J. Clin. Invest. 1990. 85:274-281.) 2',7'-bis-(2carboxyethyl)-5(and-6)carboxyfluorescein (BCECF) $\cdot \mathrm{Cl}^{-} /$ $\mathrm{HCO}_{3}^{-}$exchange $\bullet$ intercalated cell $\cdot \mathrm{Na}^{+} / \mathrm{H}^{+}$exchange $\bullet$ principal cell
\end{abstract}

\section{Introduction}

The collecting tubule of the mammalian nephron is the segment of final modulation of urinary excretion of $\mathrm{Na}^{+}, \mathrm{K}^{+}$, water, and acid-base equivalents. In the cortical collecting tubule $(C C T)^{1}$ regulation of the excretion or reabsorption of each of these occurs. Corresponding with the diversity of functions, the CCT is a heterogenous tissue composed of multiple cell types: principal cells and at least two types of intercalated cells $(1,2)$.

Address reprint requests to Dr. Hamm, Renal Division, Washington University School of Medicine, Box 8126, 660 South Euclid Avenue, St. Louis, MO 63110.

Received for publication 9 June 1989 and in revised form 12 September 1989.

1. Abbreviations used in this paper: ADH, antidiuretic hormone; BCECF, 2', 7'-bis-(2-carboxyethyl)-5(and-6)carboxyfluorescein); BCECF-AM, acetoxymethyl ester of BCECF; CCT, cortical collecting tubule; $\mathrm{pH}_{\mathrm{i}}$, intracellular $\mathrm{pH}$.

J. Clin. Invest.

(C) The American Society for Clinical Investigation, Inc. 0021-9738/90/01/0274/08 $\$ 2.00$

Volume 85, January 1990, 274-281
Principal cells are the most numerous cell type and appear to function primarily to reabsorb $\mathrm{Na}^{+}$, secrete $\mathrm{K}^{+}$, and modulate arginine-vasopressin induced water reabsorption $(3,4)$. Principal cell $\mathrm{pH}_{\mathrm{i}}$ regulation may be important in the regulation of salt and water transport by this cell. Intracellular acidosis appears to decrease $\mathrm{Na}^{+}$transport in the CCT and analogous epithelia (5-9). In addition, $\mathrm{pH}_{\mathrm{i}}$ may alter the hydroosmotic response to antidiuretic hormone (ADH) and cAMP (10-12). Conversely, ADH appears to activate numerous acid-base transporters in both renal $(13,14)$ and nonrenal tissues $(15,16)$. ADH may also have effects on urinary acidification (17).

Intercalated cells are interspersed between principal cells, make up 35-40\% of the total cells of the CCT $(1,2)$, and both secrete (18) and reabsorb $\mathrm{HCO}_{3}^{-}$(19). At least two subtypes of intercalated cells are present. The $\alpha$-intercalated cell secretes $\mathrm{H}^{+}$and reabsorbs luminal $\mathrm{HCO}_{3}^{-}$. An electrogenic, $\mathrm{H}^{+}$ translocating ATPase is present at the luminal membrane (20). $\mathrm{HCO}_{3}^{-}$exits the cell via a basolateral $\mathrm{Cl}^{-} / \mathrm{HCO}_{3}^{-}$exchanger. The $\mathrm{Cl}^{-} / \mathrm{HCO}_{3}^{-}$exchanger is sensitive to the disulfonic stilbenes (21) and is immunologically similar to the $\mathrm{Cl}^{-} / \mathrm{HCO}_{3}^{-}$ exchanger of the mammalian red blood cell, band 3 protein $(22,23)$.

The second type of intercalated cell is the $\beta$-intercalated cell. The $\beta$-intercalated cell is postulated to be responsible for $\mathrm{HCO}_{3}^{-}$secretion by the CCT. This transport is modeled to occur via a luminal $\mathrm{Cl}^{-} / \mathrm{HCO}_{3}^{-}$exchanger and a basolateral $\mathrm{H}^{+}$-ATPase. This cellular model has been derived in large part by indirect inferences from transepithelial flux measurements. The basolateral location of $\mathrm{H}^{+}$-ATPase has been confirmed by immunocytochemical studies (20). However, direct confirmation of the luminal $\mathrm{Cl}^{-} / \mathrm{HCO}_{3}^{-}$exchanger has been difficult. Antibodies to band 3 protein do not stain the apical membrane $(22,23)$ and luminal disulfonic stilbenes do not inhibit bicarbonate secretion $(21,24)$. As a result, direct confirmation of the luminal $\mathrm{Cl}^{-} / \mathrm{HCO}_{3}^{-}$exchanger in the $\beta$-intercalated cell has been lacking.

The purpose of the present studies was to characterize the distribution of the major mechanisms of $\mathrm{pH}_{\mathrm{i}}$ regulation in two of the cell types (principal cell and $\beta$-intercalated cell) present in the rabbit CCT. Evaluation of the mechanisms of $\mathrm{pH}_{\mathrm{i}}$ regulation in the CCT has been difficult due to the cellular heterogeneity of this segment of the nephron. We have recently described a technique whereby principal cell and intercalated cell $\mathrm{pH}_{\mathrm{i}}$ can be separately measured in the in vitro, microperfused rabbit CCT using the fluorescent, $\mathrm{pH}$ sensitive dye $2^{\prime}, 7^{\prime}$-bis-(2carboxyethyl)-5(and-6)carboxyfluorescein (BCECF) (25). Therefore, the specific purpose of these studies was to characterize the distribution of $\mathrm{Na}^{+} / \mathrm{H}^{+}$and $\mathrm{Cl}^{-} / \mathrm{HCO}_{3}^{-}$exchangers in the rabbit CCT.

\section{Methods}

Microperfusion. In vitro microperfusion of cortical collecting tubules was performed using standard techniques (26). Dissection of individ- 
Table I. Solutions*

\begin{tabular}{|c|c|c|c|c|c|c|c|c|}
\hline & 1 & 2 & 3 & 4 & 5 & 6 & 7 & 8 \\
\hline $\mathrm{NaCl}$ & 119.2 & - & - & 119.2 & - & 144.2 & 119.2 & - \\
\hline Choline chloride & - & 119.2 & - & - & 119.2 & - & - & - \\
\hline Sodium gluconate & - & - & 119.2 & - & - & - & 20.0 & 139.2 \\
\hline $\mathrm{NaHCO}_{3}$ & 25 & - & 25 & - & - & - & 5 & 5 \\
\hline Choline bicarbonate & - & 25 & - & - & - & - & - & - \\
\hline Hepes & - & - & - & 25 & 25 & - & - & - \\
\hline $\mathrm{KCl}$ & 3 & 2 & - & 3 & 2 & 3 & 3 & - \\
\hline Potassium gluconate & - & - & 3 & - & - & - & - & 3 \\
\hline Sodium acetate & 1 & - & 1 & 1 & - & 1 & 1 & 1 \\
\hline Potassium acetate & - & 1 & - & - & 1 & - & - & - \\
\hline $\mathrm{CaCl}_{2}$ & 1.2 & 1.2 & - & 1.2 & 1.2 & 1.2 & 1.2 & - \\
\hline Calcium gluconate & - & - & 3.4 & - & - & - & 0.5 & 5.2 \\
\hline $\mathrm{KH}_{2} \mathrm{PO}_{4}$ & 2 & 2 & 2 & 2 & 2 & 2 & 2 & 2 \\
\hline $\mathrm{MgSO}_{4}$ & 1 & 1 & 1 & 1 & 1 & 1 & 1 & 1 \\
\hline Alanine & 5 & 5 & 5 & 5 & 5 & 5 & 5 & 5 \\
\hline Glucose & 8.3 & 8.3 & 8.3 & 8.3 & 8.3 & 8.3 & 8.3 & 8.3 \\
\hline
\end{tabular}

* All concentrations expressed in millimoles per liter. Osmolality adjusted to $285-295 \mathrm{mosmol} / \mathrm{kg}$ by addition of the major salt. Solutions 4 and 5 bubbled with $100 \% \mathrm{O}_{2}$, all others with $95 \% \mathrm{O}_{2} / 5 \% \mathrm{CO}_{2}$.

ual CCT was performed in cold solution 1 (for studies with $\mathrm{CO}_{2}$ containing solutions) or in solution 4 (for studies with $\mathrm{CO}_{2}$ free solutions) (see Table I) containing 5\% fetal calf serum. Tubules were studied in a $1-\mathrm{ml}$ chamber thermostatically controlled to $37^{\circ} \mathrm{C}$; the peritubular bathing solution was continuously exchanged at a rate of $\sim 3 \mathrm{ml} / \mathrm{min}$. $\mathrm{CO}_{2}$-impermeable Saran tubing (Clarkson Equipment \& Controls, Detroit, MI) was used to deliver the bathing solution. Bath $\mathrm{pH}$ was continuously monitored with a flexible pH electrode (model MI-508; Microelectrodes, Inc., Londonderry, NH).

Solutions. The components of the various solutions used in the study are shown in Table I. Solutions 1-3, 6-8 were used for experiments performed in the presence of $\mathrm{CO}_{2}$; solutions 4 and 5 were used for experiments performed in the nominal absence of $\mathrm{CO}_{2} \cdot \mathrm{CO}_{2}$ containing solutions were bubbled with $95 \% \mathrm{O}_{2} / 5 \% \mathrm{CO}_{2} . \mathrm{CO}_{2}$-free solutions were bubbled with $100 \% \mathrm{O}_{2}$. $\mathrm{CO}_{2}$-free solutions were adjusted to pH 7.40 with tetramethylammonium hydroxide instead of sodium hydroxide in order to minimize the $\mathrm{Na}^{+}$concentration of $\mathrm{Na}^{+}$free solutions. Total $\mathrm{Ca}^{2+}$ was increased in solutions 3,7 , and 8 to compensate for complexing of $\mathrm{Ca}^{2+}$ by gluconate. All chemicals were obtained from Sigma Chemical Co. (St. Louis, MO) unless otherwise specified.

Fluorescent dyes. The acetoxymethyl ester of BCECF (BCECFAM), was obtained from Molecular Probes, Inc. (Eugene, OR) and maintained at $-20^{\circ} \mathrm{C}$ as a $30-\mathrm{mM}$ stock solution in DMSO. On the day of an experiment $15 \mu \mathrm{M}$ (for luminal loading, see below) or $5 \mu \mathrm{M}$ (for basolateral loading, see below) solutions were made by diluting with either solution 1 (for $\mathrm{CO}_{2} / \mathrm{HCO}_{3}^{-}$containing experiments) or solution 4 (for $\mathrm{CO}_{2} / \mathrm{HCO}_{3}^{-}$free experiments).

Loading with BCECF was performed as previously described (25). In brief, luminal BCECF-AM is selectively concentrated by intercalated cells, while peritubular BCECF-AM is homogeneously taken up by both principal and intercalated cells (25). As a result, intercalated cells were studied after loading with luminal BCECF-AM. Principal cells were studied by loading first with luminal BCECF-AM, identifying an area of the tubule without intercalated cells, and then loading with peritubular BCECF-AM. In all cases at least 5 min was allowed after loading BCECF-AM before measurement of $\mathrm{pH}_{\mathrm{i}}$.

Intracellular $p H$ measurements. Fluorescence studies were performed on a Nikon Diaphot-TMD microscope modified for fluorescent use as previously described (25). $\mathrm{pH}_{\mathrm{i}}$ measurements were made by exciting an area of $\sim 5 \mu \mathrm{m}$ diam. In general this field was positioned at the edge of the tubule to minimize fluorescence from cells above or below the plane of measurement. Use of a small excitation field centered at the edge of the tubule thereby allowed measurement of the $\mathrm{pH}_{\mathrm{i}}$ of either a single intercalated cell or portions of approximately one to four principal cells. $\mathrm{pH}_{\mathrm{i}}$ measurements were made by alternatively exciting at 500 and $450 \mathrm{~nm}$. Fluorescence at $530 \mathrm{~nm}$ was measured by a Nikon P1 photometer. The analog output from the photometer was digitized (8232; Starbuck Data Co., Waltham, MA) and recorded on a personal computer for analysis at a later time. Background fluorescence was $<5 \%$ of dye fluorescence at both excitation wavelengths and was subtracted before calculation of fluorescence ratio. $\mathrm{pH}_{\mathrm{i}}$ results were graphed using a moving 10-15-s time average technique. These tracings were then used for measurement of $\mathrm{pH}_{\mathrm{i}}$ for analysis. Although amiloride is a fluorescent molecule, $1 \mathrm{mM}$ peritubular amiloride had no effect on fluorescent ratio in cells which were clamped at a fixed $\mathrm{pH}_{\mathrm{i}}$ using the high- $\mathrm{K}^{+} /$Nigericin technique of Thomas et al. (27) (results not shown).

Changes in $\mathrm{pH}_{\mathrm{i}}$ after acid loading are expressed (except where specifically noted) as the difference in $\mathrm{pH}_{\mathrm{i}}$ between 1 and $5 \mathrm{~min}$ after the solution change; the initial 1-min time point was chosen to match the nadir of $\mathrm{pH}_{\mathrm{i}}$ after acid loading and to ensure complete solution change.

A change in the luminal fluid required a period of $\sim 1-3 \mathrm{~min}$ during which $\mathrm{pH}_{\mathrm{i}}$ was not measured. After completion of the perfusate change, $\mathrm{pH}_{\mathrm{i}}$ was measured for at least $5 \mathrm{~min}$ or until it had stabilized. The $\mathrm{pH}_{\mathrm{i}}$ at the end of this period was used for analysis.

Calibration. Calibration of intracellular BCECF was performed using the method of Thomas et al. (27). The calibration solution contained (in mM) $120 \mathrm{KCl}, 1.2 \mathrm{CaCl}_{2}, 1.0 \mathrm{MgCl}_{2}, 2.0 \mathrm{NaH}_{2} \mathrm{PO}_{4}, 25$ Hepes, and $14 \mu \mathrm{m}$ nigericin and was adjusted to $\mathrm{pH} 6.8,7.0,7.2,7.4$, 7.6, and 7.8 using $\mathrm{NaOH}$ and $\mathrm{HCl}$. Least-squares, linear regression was performed to fit the calibration points to the equation: ratio $(500 / 450 \mathrm{~nm})=a+b \cdot \mathrm{pH}_{\mathrm{i}}$. The calibration curve was then used for conversion of calculated fluorescent ratio to $\mathrm{pH}_{\mathrm{i}}$. Separate calibration curves were performed for intercalated cells and principal cells. In most experiments a calibration was performed for the cell type studied in that experiment and used for conversion of calculated ratio to $\mathrm{pH}_{\mathrm{i}}$; in a few experiments mean calibration curves from prior experiments were used for conversion. Dye concentration during calibration, as measured by fluorescence at $450 \mathrm{~nm}$ excitation, was similar to that during experimental $\mathrm{pH}_{\mathrm{i}}$ measurements.

Acid loading. Acid loading was achieved by changing the peritubular solution to one containing $10 \mathrm{mM} \mathrm{NH}_{4} \mathrm{Cl}$ (for principal cells and some $\beta$-intercalated cells) or $20 \mathrm{mM} \mathrm{NH}_{4} \mathrm{Cl}$ (for some $\beta$-intercalated 
cells) for a period of $5 \mathrm{~min}$; removal of $\mathrm{NH}_{4} \mathrm{Cl}$ resulted in an abrupt acidification. Equimolar amounts of the principal salt in the $\mathrm{NH}_{4} \mathrm{Cl}$ containing solutions were removed so that solution osmolality remained constant. Although $20 \mathrm{mM} \mathrm{NH}_{4} \mathrm{Cl}$ resulted in slightly greater acidification, no qualitative differences in results were seen.

Statistics. Values are presented as mean \pm SEM. In general, statistical tests are performed using paired, two sided Student's $t$ test. Unpaired, two-sided Student's $t$ tests were used when appropriate and are noted in the text. Statistical significance is defined as at least $P<0.05$. All $\mathrm{pH}_{\mathrm{i}}$ results are reported as the mean of $n$ tubules.

\section{Results}

Principal cell $p H_{i}$. Baseline $\mathrm{pH}_{\mathrm{i}}$ for principal cells was obtained in tubules bathed and perfused with identical solutions for at least 30 min before any measurements. The baseline $\mathrm{pH}_{\mathrm{i}}$ in $\mathrm{CO}_{2}$ containing solutions (solution 1$)$ was $7.36 \pm 0.05(n=13)$, while in the absence of $\mathrm{CO}_{2}$ (solution 4$)$ the baseline $\mathrm{pH}_{\mathrm{i}}$ was significantly higher at $7.77 \pm 0.06(n=13)(P<0.001$ by unpaired $t$ test).

Principal cell $\mathrm{Na}^{+} / \mathrm{H}^{+}$exchange. The importance of $\mathrm{Na}^{+} / \mathrm{H}^{+}$exchange on principal cell $\mathrm{pH}_{\mathrm{i}}$ recovery after an acid load was investigated. All experiments evaluating principal cell $\mathrm{Na}^{+} / \mathrm{H}^{+}$exchange were performed in $\mathrm{CO}_{2} / \mathrm{HCO}_{3}^{-}$free solutions in order to minimize the effect of $\mathrm{HCO}_{3}^{-}$transporters on $\mathrm{pH}_{\mathrm{i}}$ regulation. A 5-min application and then removal of 10 $\mathrm{mM}$ ammonium chloride (solution 5 plus $\mathrm{NH}_{4} \mathrm{Cl}$ ) was used to acidify principal cells to a mean $\mathrm{pH}_{\mathrm{i}}$ of $6.84 \pm 0.09(n=10)$. After $5 \mathrm{~min}$ in a $\mathrm{Na}^{+}$free peritubular solution (solution 5 ) principal cell $\mathrm{pH}_{\mathrm{i}}$ increased by only $0.16 \pm 0.11 \mathrm{pH} \mathrm{U}(n=6$, NS from 0.00 ). By contrast, after $5 \mathrm{~min}$ in a $\mathrm{Na}^{+}$containing peritubular solution (solution 4$), \mathrm{pH}_{\mathrm{i}}$ in the same principal cells increased $0.50 \pm 0.05 \mathrm{pH} \mathrm{U}\left(n=6, P<0.05 \mathrm{vs}\right.$. $\mathrm{Na}^{+}$free $)$. These results show that principal cells possess a $\mathrm{Na}^{+}$dependent mechanism for $\mathrm{pH}_{\mathrm{i}}$ regulation after an acid load. (In most experiments the peritubular bathing solution was changed first to a $\mathrm{Na}^{+}$free solution for $5 \mathrm{~min}$ and then to the $\mathrm{Na}^{+}$containing peritubular solution; the principal cells were generally at the same, or occasionally slightly higher, initial $\mathrm{pH}_{\mathrm{i}}$ on exposure to the $\mathrm{Na}^{+}$containing solution. Since the $\mathrm{Na}^{+} / \mathrm{H}^{+}$exchanger has been well characterized to be inhibited by an increased $\mathrm{pH}_{\mathrm{i}}$, the increased rate of recovery of $\mathrm{pH}_{\mathrm{i}}$ during $\mathrm{Na}^{+}$containing basolateral solutions cannot be explained by the difference in the initial $\mathrm{pH}_{\mathrm{i}}$.)

To confirm this $\mathrm{Na}^{+}$dependent $\mathrm{pH}_{\mathrm{i}}$ recovery as $\mathrm{Na}^{+} / \mathrm{H}^{+}$ exchange, the inhibitory effect of $1 \mathrm{mM}$ amiloride on $\mathrm{pH}_{\mathrm{i}}$ recovery after an acid load was investigated. A typical experiment is shown in Fig. 1. In the presence of peritubular amiloride, the $\mathrm{pH}_{\mathrm{i}}$ recovery after $5 \mathrm{~min}$ was $0.13 \pm 0.05 \mathrm{pH} \mathrm{U}$, while in the absence of amiloride $\mathrm{pH}_{\mathrm{i}}$ recovery in the same cells was $0.67 \pm 0.08$ ( $n=7, P<0.005$ by paired $t$ test). These results suggest that a basolateral, amiloride inhibitable, $\mathrm{Na}^{+}$-dependent mechanism, i.e., $\mathrm{Na}^{+} / \mathrm{H}^{+}$exchange, is a major mechanism for principal cell recovery from an acid load.

To determine if $\mathrm{Na}^{+} / \mathrm{H}^{+}$exchange is active at baseline $\mathrm{pH}_{\mathrm{i}}$, the effect of $\mathrm{Na}^{+}$removal on principal cell $\mathrm{pH}_{\mathrm{i}}$ was investigated. Removal of $\mathrm{Na}^{+}$from the peritubular solution (changing to solution 5) resulted in a slow acidification of $0.10 \pm 0.04$ pH U $(n=8, P<0.05)$ over a 5 -min period.

$\mathrm{Cl}^{-}$and principal cell $\mathrm{pH}_{i} \mathrm{Cl}^{-}$dependent $\mathrm{pH}_{\mathrm{i}}$ regulatory processes appear to be present in most cell types (28); the presence of these was investigated next. Removal of $\mathrm{Cl}^{-}$from

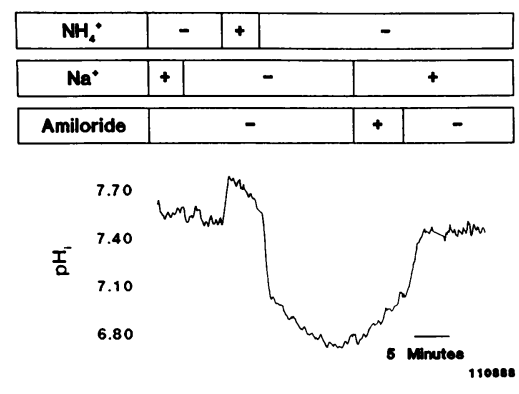

Figure 1. Effect of peritubular $\mathrm{Na}^{+}$and amiloride on principal cell $\mathrm{pH}_{\mathrm{i}}$ recovery after an acid load. The ammonium chloride pulse technique is used to acid load the cells. In the absence of peritubular $\mathrm{Na}^{+}$almost no recovery from intracellular acidification takes

place, in fact there is a slow continued acidification in this experiment. When the peritubular solution is changed to one containing 1 $\mathrm{mM}$ amiloride and $\sim 145 \mathrm{mM} \mathrm{Na}^{+}$there is some recovery of $\mathrm{pH}_{\mathrm{i}}$. However, removal of amiloride results in a marked increase in rate of $\mathrm{pH}_{\mathrm{i}}$ recovery and a rapid return of $\mathrm{pH}_{\mathrm{i}}$ to baseline. Not well demonstrated in this experiment is a slow acidification during removal of peritubular $\mathrm{Na}^{+}$before the ammonium chloride pulse. In general, $\mathrm{Na}^{+}$free and amiloride containing protocols were not performed on the same principal cell (as performed in this experiment).

$\mathrm{CO}_{2} / \mathrm{HCO}_{3}^{-}$containing luminal solutions (changing the perfusate from solution 1 to solution 3 ) for 5-10 min resulted in no significant change in principal cell $\mathrm{pH}_{\mathrm{i}}$ (difference $-0.02 \pm 0.03, P=\mathrm{NS}, n=4)$. Similarly, return of $\mathrm{Cl}^{-}$to the luminal fluid (change back to solution 1) resulted in no significant change in $\mathrm{pH}_{\mathrm{i}}$ (difference $\left.-0.01 \pm 0.04, P=\mathrm{NS}, n=4\right)$. Evidence for a basolateral $\mathrm{Cl}^{-}$linked $\mathrm{pH}_{\mathrm{i}}$ regulatory mechanism was then studied. A 5-min removal and then return of $\mathrm{Cl}^{-}$to the peritubular solution (change from solution 1 to solution 3 and then return to solution 1) resulted in no significant changes in principal cell $\mathrm{pH}_{\mathrm{i}}$ (differences $-0.02 \pm 0.03$ and $-0.06 \pm 0.03$, for removal and return of peritubular $\mathrm{Cl}^{-}$, respectively, $n=5, P=$ NS for both). However, since intracellular $\mathrm{Cl}^{-}$concentrations in principal cells are quite low, $\sim 7-14$ $\mathrm{mmol} / \mathrm{kg}$ dry wt in the rat $(29,30)$ and principal cells possess a basolateral $\mathrm{Cl}^{-}$channel (31), removal of peritubular $\mathrm{Cl}^{-}$may result in gradients for $\mathrm{Cl}^{-} / \mathrm{HCO}_{3}^{-}$exchange that are relatively small, possibly explaining the relative absence of $\mathrm{pH}_{\mathrm{i}}$ changes after 5 min of peritubular $\mathrm{Cl}^{-}$removal. A prolonged removal of peritubular $\mathrm{Cl}^{-}$might result in intracellular $\mathrm{Cl}^{-}$depletion and an increased gradient for $\mathrm{Cl}^{-}$entry during return of $\mathrm{Cl}^{-}$to the peritubular solution. A 30 -min incubation in a $\mathrm{Cl}^{-}$free peritubular solution (solution 3 ) resulted in a slow increase in $\mathrm{pH}_{\mathrm{i}}$ from $7.35 \pm 0.08$ to a maximum of $7.55 \pm 0.10(P<0.005, n$ $=5$ ). After return of peritubular $\mathrm{Cl}^{-}$(change back to solution 1) $\mathrm{pH}_{\mathrm{i}}$ fell rapidly. $5 \mathrm{~min}$ after the change $\mathrm{pH}_{\mathrm{i}}$ had fallen by $0.30 \pm 0.04 \mathrm{pH} \mathrm{U}(P<0.005$ by paired $t$ test, $n=5)$. These results are consistent with the exchange of intracellular $\mathrm{HCO}_{3}^{-}$ for extracellular $\mathrm{Cl}^{-}$, i.e., basolateral $\mathrm{Cl}^{-} / \mathrm{HCO}_{3}^{-}$exchange activity, during the return of basolateral $\mathrm{Cl}^{-}$to $\mathrm{Cl}^{-}$depleted principal cells.

Intercalated cell-baseline $\mathrm{pH}_{i}$ and $\mathrm{CO}_{2} / \mathrm{HCO}_{3}^{-}$. $\beta$-intercalated cell baseline $\mathrm{pH}_{\mathrm{i}}$ was measured in the presence and absence of $\mathrm{CO}_{2} / \mathrm{HCO}_{3}^{-}$. In the presence of $\mathrm{CO}_{2} / \mathrm{HCO}_{3}^{-}$(luminal and peritubular solution 1) the baseline $\mathrm{pH}_{\mathrm{i}}$ was $7.33 \pm 0.04$ ( $n$ $=32$ ). In the nominal absence of $\mathrm{HCO}_{3}^{-} / \mathrm{CO}_{2}$ (luminal and peritubular solution 4 ), $\beta$-intercalated cell $\mathrm{pH}_{\mathrm{i}}$ was $8.05 \pm 0.02$ ( $n=4, P<0.001$ vs. $\mathrm{pH}_{\mathrm{i}}$ in the presence of $\mathrm{CO}_{2} / \mathrm{HCO}_{3}^{-}$by unpaired $t$ test). However, BCECF may not reliably reflect true $\mathrm{pH}_{\mathrm{i}}$ at such extremes of $\mathrm{pH}$. Consistent with this is the finding 
that in the nominal absence of $\mathrm{CO}_{2}$ and $\mathrm{HCO}_{3}^{-}$no change was seen in $\beta$-intercalated cell apparent $\mathrm{pH}_{\mathrm{i}}$ with either addition or removal of basolateral $\mathrm{NH}_{4}^{+}$(data not shown). Therefore, all subsequent intercalated cells experiments were performed with $\mathrm{CO}_{2}$ present in the both the peritubular and luminal solutions.

Intercalated cells, identification of subtype by $\mathrm{Cl}^{-}$removal. Basolateral $\mathrm{Cl}^{-}$removal resulted in two distinct patterns of $\mathrm{pH}_{\mathrm{i}}$ response in intercalated cells. Occasional cells underwent a rapid alkalinization from $\mathrm{pH}_{\mathrm{i}} 7.17 \pm 0.07$ to $7.64 \pm 0.05(n=5$, $P<0.001$ ) after basolateral $\mathrm{Cl}^{-}$removal. This was completely reversible with return of $\mathrm{Cl}^{-}$to the peritubular solution, consistent with the presence of a basolateral $\mathrm{Cl}^{-} / \mathrm{HCO}_{3}^{-}$exchanger. A representative experiment is shown in Fig. 2. These cells were infrequently encountered and further data will not be presented.

The majority of intercalated cells underwent a rapid intracellular acidification after basolateral $\mathrm{Cl}^{-}$removal, functionally identifying it as the $\beta$-intercalated cell. The response of intercalated cells to basolateral $\mathrm{Cl}^{-}$removal allows for a functional differentiation of the two types of intercalated cells. In all experiments on $\beta$-intercalated cells, sub-type was confirmed by intracellular acidosis in response to basolateral $\mathrm{Cl}^{-}$removal.

In $\beta$-intercalated cells with basolateral $\mathrm{Cl}^{-}$removal, the average decrease in $\mathrm{pH}_{\mathrm{i}}$ was $-0.70 \pm 0.04 \mathrm{pH} \mathrm{U}$ in $3.9 \pm 0.04$ $\min (n=28, P<0.001)$. Return of basolateral $\mathrm{Cl}^{-}$resulted in the return of $\mathrm{pH}_{\mathrm{i}}$ to baseline. This has been reported by others and hypothesized to result from acceleration of apical $\mathrm{Cl}^{-} /$ $\mathrm{HCO}_{3}^{-}$exchange (32). To examine this hypothesis the effects of luminal $\mathrm{Cl}^{-}$and $\mathrm{HCO}_{3}^{-}$on $\mathrm{pH}_{\mathrm{i}}$ was examined. Nominal removal of $\mathrm{HCO}_{3}^{-}$from the luminal solution (change to solution 6) resulted in a decrease of $0.41 \pm 0.05 \mathrm{pH} \mathrm{U}(P<0.005, n=8)$. Luminal $\mathrm{Cl}^{-}$removal (change to solution 3) caused $\mathrm{pH}_{\mathrm{i}}$ to increase $0.45 \pm 0.07 \mathrm{pH} \mathrm{U}(n=7, P<0.005)$. Furthermore, the removal of luminal $\mathrm{Cl}^{-}$blocked the effect of basolateral $\mathrm{Cl}^{-}$ removal on intracellular pH (see Fig. 3). Removal of basolateral $\mathrm{Cl}^{-}$(by changing to solution 3 ) in the absence of luminal $\mathrm{Cl}^{-}$resulted in no significant change in $\mathrm{pH}_{\mathrm{i}}(-0.11 \pm 0.07, n$ $=6, P=\mathrm{NS}$ ). The subsequent return of luminal $\mathrm{Cl}^{-}$in the absence of basolateral $\mathrm{Cl}^{-}$resulted in a marked acidification $(\Delta$ $\mathrm{pH}_{\mathrm{i}}=-0.73 \pm 0.18, n=6, P<0.01$ ). This $\mathrm{pH}_{\mathrm{i}}$ is not significantly different than the $\mathrm{pH}_{\mathrm{i}}$ present after basolateral $\mathrm{Cl}^{-}$removal $(P>0.3$, unpaired $t$ test $)$, consistent with changes in $\mathrm{pH}_{\mathrm{i}}$ via identical mechanisms.

One likely explanation for the decrease in $\mathrm{pH}_{\mathrm{i}}$ with luminal $\mathrm{HCO}_{3}^{-}$removal is the exchange of intracellular $\mathrm{HCO}_{3}^{-}$for luminal $\mathrm{Cl}^{-}$via an apical $\mathrm{Cl}^{-} / \mathrm{HCO}_{3}^{-}$exchanger. Therefore the effect of luminal $\mathrm{Cl}^{-}$on $\beta$-intercalated cell response to a de-

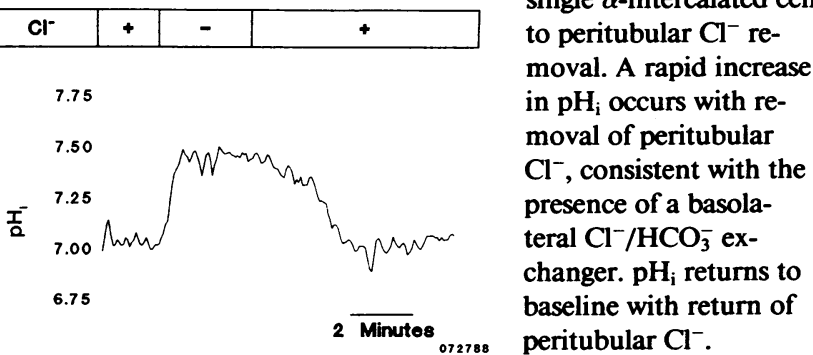

\begin{tabular}{|l|l|l|l|l|l|}
\hline Lumen $\mathrm{Cl}^{-}$ & + & \multicolumn{2}{|c|}{-} & \multicolumn{2}{|c|}{+} \\
\hline Bath $\mathrm{Cl}^{-}$ & + & - & + & & - \\
\hline
\end{tabular}

Figure 3. Effect of lumen and bath $\mathrm{Cl}^{-}$removal on $\beta$-intercalated cell $\mathrm{pH}_{\mathrm{i}} \cdot \mathrm{pH}_{\mathrm{i}}$ rapidly falls to very low levels
6.20

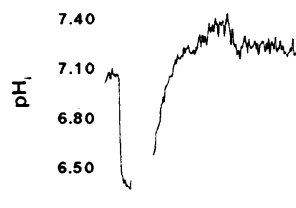

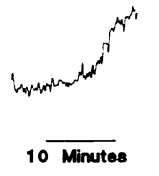

03018802 with removal of peritubular ("bath") $\mathrm{Cl}^{-}$. $\mathrm{Re}$ moval of luminal $\mathrm{Cl}^{-}$, in the continued absence of peritubular $\mathrm{Cl}^{-}$, reverses the acidification and returns $\mathrm{pH}_{\mathrm{i}}$

to slightly above baseline. The return of peritubular $\mathrm{Cl}^{-}$results in further alkalinization. When peritubular $\mathrm{Cl}^{-}$is removed a second time, but now in the absence of luminal $\mathrm{Cl}^{-}$, there is only a very slight acidification, markedly less than the acidification when luminal $\mathrm{Cl}^{-}$is present, thereby suggesting that the acidification is due to a luminal $\mathrm{Cl}^{-}$dependent process. This is confirmed by the readdition of luminal $\mathrm{Cl}^{-}$resulting in cell acidification. Return of peritubu$\operatorname{lar} \mathrm{Cl}^{-}$then returns $\mathrm{pH}_{\mathrm{i}}$ to baseline levels.

crease in luminal $\mathrm{HCO}_{3}^{-}$concentration was evaluated. Gluconate was substituted for the removed $\mathrm{HCO}_{3}^{-}$so that luminal $\mathrm{Cl}^{-}$would remain constant. In the presence of luminal $\mathrm{Cl}^{-}$, decreasing perfusate $\mathrm{HCO}_{3}^{-}$from 25 to $5 \mathrm{meq} /$ liter (changing from solution 1 to 7) caused $\mathrm{pH}_{\mathrm{i}}$ to decrease $0.24 \pm 0.06 \mathrm{pH} \mathrm{U}$ $(P<0.025, n=4)$. In the absence of luminal $\mathrm{Cl}^{-}$there was no significant change in $\mathrm{pH}_{\mathrm{i}}$ (change from solution 3 to $8, \Delta$ $=+0.05 \pm 0.03, P=$ NS vs. $0.00, P<0.01$ vs. changes in the presence of luminal $\mathrm{Cl}^{-}$by paired $t$ test, $n=4$ ). (In additional experiments to test this model, tubules were bathed and perfused with a high $\mathrm{K}^{+}$solution containing $5 \mu \mathrm{M}$ valinomycin in order to voltage clamp both the apical and basolateral membranes. Removal of luminal $\mathrm{Cl}^{-}$caused $\mathrm{pH}_{\mathrm{i}}$ to reversibly increase $0.20 \pm 0.05 \mathrm{pH} \mathrm{U}[n=2]$. This is consistent with an apical, electroneutral, $\mathrm{Cl}^{-}$dependent, base exit process, i.e., $\mathrm{Cl}^{-} / \mathrm{HCO}_{3}^{-}$exchange. However, perfusion of $\mathrm{CCT}$ with high $\mathrm{K}^{+}$solutions results in marked cell swelling [33, 34, and personal observations] and hence this method was not pursued further.)

These results suggest that $\mathrm{Cl}^{-}$/base exchange at the apical membrane, in series with a basolateral $\mathrm{Cl}^{-}$transport mechanism, most likely a $\mathrm{Cl}^{-}$channel (35), is present in the $\beta$-intercalated cell.

$\beta$-intercalated cell $\mathrm{Na}^{+} / \mathrm{H}^{+}$exchange. $\beta$-Intercalated cells were examined for the presence or absence of basolateral $\mathrm{Na}^{+} / \mathrm{H}^{+}$exchange activity. The ammonium chloride pulse technique was used to acid load the cells to a mean $\mathrm{pH}_{\mathrm{i}}$ of 6.77 $\pm 0.07(n=16)$. A typical experiment is shown in Fig. 4. In a $\mathrm{Na}^{+}$free peritubular solution (solution 2 ) $\mathrm{pH}_{\mathrm{i}}$ recovered $0.08 \pm 0.04 \mathrm{pH} \mathrm{U}(n=11)$ after $5 \mathrm{~min}$. When $\mathrm{Na}^{+}$was returned to the peritubular solution $\mathrm{pH}_{\mathrm{i}}$ recovery was markedly increased to $0.38 \pm 0.07 \mathrm{pH} \mathrm{U}(n=11, P<0.001$ by paired $t$ test).

The inhibitory effect of basolateral amiloride on $\mathrm{pH}_{\mathrm{i}}$ recovery of $\beta$-intercalated cells was then investigated. A concentration of $1 \mathrm{mM}$ amiloride was used (in solution 1) in order to achieve a high degree of inhibition of the $\mathrm{Na}^{+} / \mathrm{H}^{+}$exchange (36). Results are summarized in Fig. 5. After intracellular acid loading, the $\mathrm{pH}_{\mathrm{i}}$ recovery at $5 \mathrm{~min}$ in the presence of amiloride was $0.05 \pm 0.04$, while in the absence of amiloride the recovery was $0.37 \pm 0.05 \mathrm{pH} \mathrm{U}(n=5, P<0.025)$. $\beta$-intercalated cell recovery from an acid load is via a basolateral $\mathrm{Na}^{+}$dependent, amiloride inhibitable mechanism, i.e., $\mathrm{Na}^{+} / \mathrm{H}^{+}$exchange. 


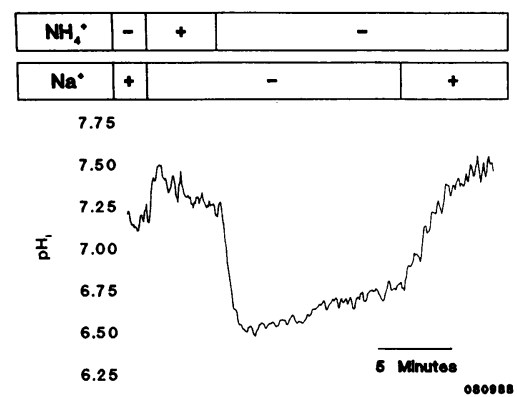

Figure 4. $\mathrm{Na}^{+}$dependence of $\beta$-intercalated cell $\mathrm{pH}_{\mathrm{i}}$ recovery after an acid load. The ammonium chloride pulse technique was used for acid loading and $\mathrm{pH}_{\mathrm{i}}$ in a single $\beta$-intercalated cell measured (see text for details). In the absence of peritubular $\mathrm{Na}^{+}$little recovery of $\mathrm{pH}_{\mathrm{i}}$ occurred. When $\mathrm{Na}^{+}$was returned to the peritubular solution there was a rapid recovery of $\mathrm{pH}_{\mathrm{i}}$ to baseline levels.

Mechanism of $\mathrm{pH}_{i}$ recovery in $\beta$-intercalated cells after basolateral $\mathrm{Cl}^{-}$removal. Basolateral $\mathrm{Cl}^{-}$removal from $\beta$-intercalated cells results in a marked acidification as described above. These intercalated cells possess multiple acid-base transporters (basolateral $\mathrm{Na}^{+} / \mathrm{H}^{+}$exchange, luminal $\mathrm{Cl}^{-} /$ $\mathrm{HCO}_{3}^{-}$exchange, and basolateral $\mathrm{H}^{+}$-ATPase; see introduction) which may participate in regulation of $\mathrm{pH}_{\mathrm{i}}$. Yet in the continued absence of basolateral $\mathrm{Cl}^{-}$for up to $10 \mathrm{~min}$, no significant recovery of $\mathrm{pH}_{\mathrm{i}}$ occurred (data not shown), despite the presence of basolateral $\mathrm{Na}^{+}$. To examine the activity of basolateral $\mathrm{Na}^{+} / \mathrm{H}^{+}$during the absence of basolateral $\mathrm{Cl}^{-}$(and therefore a low $\mathrm{pH}_{\mathrm{i}}$ ), the effect of amiloride was studied. Peritubular amiloride ( $1 \mathrm{mM}$ dissolved in solution 3 ) resulted in a further decrease in $\mathrm{pH}_{\mathrm{i}}$ of $0.40 \pm 0.13 \mathrm{pH} \mathrm{U}(n=7, P<0.025)$ after $5 \mathrm{~min}$. This decrease was reversible with the removal of amiloride, suggesting that $\beta$-intercalated cell basolateral $\mathrm{Na}^{+} / \mathrm{H}^{+}$exchange is active during the absence of basolateral $\mathrm{Cl}^{-}$.

\section{Discussion}

These studies address the mechanisms of $\mathrm{pH}_{\mathrm{i}}$ regulation in the rabbit CCT. The three major cell types (principal cell, $\alpha$-intercalated cell, and $\beta$-intercalated cell) of this segment of the nephron were studied separately utilizing differences in BCECF loading characteristics (25) and response to peritubular $\mathrm{Cl}^{-}$removal (32). The markedly different responses of the different cell types to peritubular $\mathrm{Cl}^{-}$removal serve to substantiate our method of studying these cell types separately. The location of $\mathrm{Na}^{+} / \mathrm{H}^{+}$exchange and $\mathrm{Cl}^{-} / \mathrm{HCO}_{3}^{-}$exchange

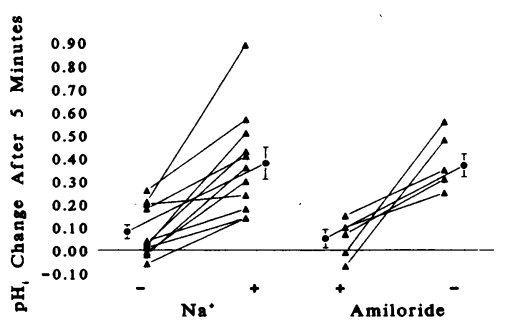

Figure 5. Inhibition of $\beta$-intercalated cell $\mathrm{pH}_{\mathrm{i}}$ recovery by peritubular $\mathrm{Na}^{+}$removal and by amiloride. In the absence of peritubular $\mathrm{Na}^{+}, \beta$-intercalated cell $\mathrm{pH}_{\mathrm{i}}$ recovery was only $0.08 \pm 0.04 \mathrm{pH} U$ after 5 min. In the presence of

$\mathrm{Na}^{+}, \mathrm{pH}_{\mathrm{i}}$ recovery in the same $\beta$-intercalated cells was $0.38 \pm 0.07 \mathrm{pH}$ $\mathrm{U}(P<0.001)$. Similarly, $1 \mathrm{mM}$ peritubular amiloride decreased $\beta$ intercalated cell $\mathrm{pH}_{\mathrm{i}}$ recovery from $0.37 \pm 0.05$ to $0.05 \pm 0.04 \mathrm{pH} \mathrm{U}$ after $5 \mathrm{~min}(P<0.025)$. Lines connect $\mathrm{pH}_{\mathrm{i}}$ recovery in the same $\beta$ intercalated cell. ( $\Delta$, individual $\beta$-intercalated cell, $\bullet$, mean \pm SEM). were studied in particular because of the apparent ubiquity of these transporters in mammalian cells.

The first major result of these studies is the demonstration that $\mathrm{Na}^{+} / \mathrm{H}^{+}$exchange is present at the basolateral membrane of both principal cells and $\beta$-intercalated cells. Principal cell $\mathrm{pH}_{\mathrm{i}}$ recovery after an acid load was $\mathrm{Na}^{+}$-dependent and amiloride inhibitable. The use of nominally $\mathrm{CO}_{2} / \mathrm{HCO}_{3}^{-}$free solutions minimizes the likelihood that $\mathrm{Na}^{+}$-dependent $\mathrm{HCO}_{3}^{-}$ transport was responsible for the observed $\mathrm{pH}_{\mathrm{i}}$ changes. The most likely mechanism for an amiloride-sensitive, $\mathrm{Na}^{+}$-dependent recovery from an acid load is a $\mathrm{Na}^{+} / \mathrm{H}^{+}$exchanger. Although not specifically tested, this exchanger is apparently present only on the basolateral membrane since little, if any, $\mathrm{pH}_{\mathrm{i}}$ recovery occurred with no peritubular $\mathrm{Na}^{+}$, even in the presence of luminal $\mathrm{Na}^{+}$.

A basolateral membrane $\mathrm{Na}^{+} / \mathrm{H}^{+}$exchanger was also identified in the $\beta$-intercalated cell. In the absence of basolateral $\mathrm{Na}^{+}$, almost no recovery of $\mathrm{pH}_{\mathrm{i}}$ occurred from ammonium chloride pulse-induced intracellular acidosis. Amiloride resulted in a similar inhibition of $\mathrm{pH}_{\mathrm{i}}$ recovery after an acid load. Since the studies on $\beta$-intercalated cells were performed in $\mathrm{CO}_{2} / \mathrm{HCO}_{3}^{-}$containing solutions, it is possible that the recovery was via $\mathrm{HCO}_{3}^{-}$transporters. Multiple $\mathrm{Na}^{+}$-linked $\mathrm{HCO}_{3}^{-}$ transporters, such as $\mathrm{Na}\left(\mathrm{HCO}_{3}^{-}\right)_{3}^{-2}=(37,38)$ and $\mathrm{Na}^{+}$-dependent $\mathrm{Cl}^{-} / \mathrm{HCO}_{3}^{-}$exchange (39), are known to exist. However, amiloride has not been shown to inhibit any of these (36). These results therefore provide the first evidence that basolateral $\mathrm{Na}^{+} / \mathrm{H}^{+}$exchange is present in the $\beta$-intercalated cell.

$\mathrm{Na}^{+} / \mathrm{H}^{+}$exchange is a major mechanism of $\mathrm{pH}_{\mathrm{i}}$ regulation after acid loads in almost every cell in which it has been studied (40). It also may be involved in growth factor signal transduction (41), cell volume regulation (42), and transepithelial $\mathrm{Na}^{+}$transport (as in the proximal tubule, for example [43]). Boron et al. (44) has identified a Na${ }^{+} / \mathrm{H}^{+}$exchanger on the basolateral membrane of the rabbit CCT. Although intercalated and principal cells could not be differentiated by their techniques, they concluded that $\mathrm{Na}^{+} / \mathrm{H}^{+}$exchange was present at the basolateral membrane of principal cells of the rabbit CCT because of the predominance of principal cells and because $\mathrm{Na}^{+} / \mathrm{H}^{+}$exchanger activity was seen in all experiments. In addition, they too found no evidence for luminal $\mathrm{Na}^{+} / \mathrm{H}^{+}$ exchange activity in the CCT. The results of the present study extend their findings by demonstrating the presence of a basolateral $\mathrm{Na}^{+} / \mathrm{H}^{+}$exchanger in both principal cells and $\beta$-intercalated cells. Breyer et al. (45) and Hays et al. (46) have demonstrated basolateral $\mathrm{Na}^{+} / \mathrm{H}^{+}$exchange in the inner stripe of the outer medullary collecting duct, which appears to be functionally equivalent to the $\alpha$-intercalated cell in the CCT. $\mathrm{Na}^{+} / \mathrm{H}^{+}$exchange has also been shown in papillary collecting tubule cells $(47,48)$. Therefore, all cells of the collecting tubule probably have basolateral $\mathrm{Na}^{+} / \mathrm{H}^{+}$exchange.

The finding that the major mechanism of $\mathrm{pH}_{\mathrm{i}}$ recovery in $\beta$-intercalated cells was $\mathrm{Na}^{+} / \mathrm{H}^{+}$exchange was initially quite surprising. These cells presumably have basolateral $\mathrm{H}^{+}$-ATPase (20), and intracellular acidification may stimulate the insertion of additional $\mathrm{H}^{+}$-ATPase from endosomes $(49,50)$. The inhibition of $\mathrm{pH}_{\mathrm{i}}$ recovery by the absence of basolateral $\mathrm{Na}^{+}$or the presence of amiloride suggests that $\mathrm{H}^{+}$-ATPase is not a major factor in acute $\mathrm{pH}_{\mathrm{i}}$ regulation in the $\beta$-intercalated cell. Several factors may account for the observation that $\mathrm{Na}^{+}$ independent processes (i.e., $\mathrm{H}^{+}$-ATPase) apparently do not contribute significantly to acute $\mathrm{pH}_{\mathrm{i}}$ recovery. Membrane $\mathrm{H}^{+}$- 
ATPase activity appears to be regulated by insertion of $\mathrm{H}^{+}$ATPase into and removal from the plasma membrane via exocytosis and endocytosis, respectively (49-51). This process might not allow $\mathrm{H}^{+}$-ATPase to acutely regulate $\mathrm{pH}_{\mathrm{i}}$. To the extent that endocytosis and exocytosis of $\mathrm{H}^{+}$-ATPase might acutely regulate $\mathrm{pH}_{\mathrm{i}}$, the intracellular alkalinization during the application of ammonium chloride could lead to endocytosis of $\mathrm{H}^{+}$from the basolateral membrane (51), thereby relatively decreasing the potential $\mathrm{H}^{+}$-ATPase-mediated $\mathrm{pH}_{\mathrm{i}}$ recovery during the first $5 \mathrm{~min}$ of acidosis. Also possible is that this cell, which functions to secrete base into the urine, might turn-off the mechanisms of $\mathrm{HCO}_{3}^{-}$secretion, e.g., $\mathrm{H}^{+}$-ATPase, in response to intracellular acidosis. These considerations and the results of this study suggest that a basolateral $\mathrm{Na}^{+} / \mathrm{H}^{+}$exchanger participates in the regulation of $\beta$-intercalated cell $\mathrm{pH}_{\mathrm{i}}$; insertion of $\mathrm{H}^{+}$-ATPase into the basolateral membrane of the $\beta$-intercalated cell may be geared toward transepithelial $\mathrm{HCO}_{3}^{-}$transport and not acute $\mathrm{pH}_{\mathrm{i}}$ regulation.

Does the basolateral $\mathrm{Na}^{+} / \mathrm{H}^{+}$exchanger in $\beta$-intercalated cells have some role in CCT bicarbonate secretion? Recent studies by Star et al. (52) found that bilateral (luminal and basolateral) $\mathrm{Na}^{+}$removal did not affect rabbit $\mathrm{CCT} \mathrm{HCO}_{3}^{-}$ secretion. However, other studies have differed. McKinney and Burg studied $\mathrm{HCO}_{3}^{-}$secreting $\mathrm{CCT}$ and found that bicarbonate secretion was dependent on peritubular $\mathrm{Na}^{+}(18)$. Arruda et al. (53) showed in the turtle bladder (a model epithelium for the CCT) that bilateral $\mathrm{Na}^{+}$removal decreased $\mathrm{HCO}_{3}^{-}$ secretion. Further studies are necessary to delineate the role, if any, of $\mathrm{Na}^{+} / \mathrm{H}^{+}$exchange in $\mathrm{CCT} \mathrm{HCO}_{3}^{-}$secretion.

The other major class of acid-base transporters examined in this study was the $\mathrm{Cl}^{-} / \mathrm{HCO}_{3}^{-}$exchange process. Principal cell $\mathrm{Cl}^{-} / \mathrm{HCO}_{3}^{-}$exchange was carefully examined. Short-term ( $5 \mathrm{~min}$ ) removal of either luminal or basolateral $\mathrm{Cl}^{-}$did not result in a significant change in $\mathrm{pH}_{\mathrm{i}}$. A prolonged removal and then return of basolateral $\mathrm{Cl}^{-}$was necessary to demonstrate changes in principal cell $\mathrm{pH}_{\mathrm{i}}$, consistent with the presence of a basolateral $\mathrm{Cl}^{-} / \mathrm{HCO}_{3}^{-}$exchanger, albeit relatively inactive. This transporter clearly differs from that in the $\alpha$ - and $\beta$-intercalated cells. First, $\mathrm{pH}_{\mathrm{i}}$ in $\alpha$ - and $\beta$-intercalated cells responds rapidly and dramatically to peritubular $\mathrm{Cl}^{-}$removal (see Figs. 2 and 3). Next, the principal cell $\mathrm{Cl}^{-} / \mathrm{HCO}_{3}^{-}$exchanger does not cross-react with antibodies to band 3 protein, as does the $\mathrm{Cl}^{-} / \mathrm{HCO}_{3}^{-}$exchanger of the $\alpha$-intercalated cell $(22,23)$. Finally, it is located at the opposite membrane from the $\beta$-intercalated cell $\mathrm{Cl}^{-} / \mathrm{HCO}_{3}^{-}$exchanger. The role of the principal cell $\mathrm{Cl}^{-} / \mathrm{HCO}_{3}^{-}$exchanger is not known, but it could function in recovery from intracellular alkalosis, as $\mathrm{Cl}^{-} / \mathrm{HCO}_{3}^{-}$exchangers do in many other cell types $(28,45,54)$. The minimal (and slow) response to basolateral $\mathrm{Cl}^{-}$removal in principal cells is consistent with relative inactivity of this transporter at baseline $\mathrm{pH}_{\mathrm{i}}$ and confirms that the principal cell is not involved significantly in transepithelial $\mathrm{HCO}_{3}^{-}$transport.

In intercalated cells, basolateral $\mathrm{Cl}^{-}$removal resulted in opposite $\mathrm{pH}_{\mathrm{i}}$ responses in two different populations. Schwartz et al. (32) first showed this differential $\mathrm{pH}_{\mathrm{i}}$ response to basolateral $\mathrm{Cl}^{-}$removal. In the present studies, the majority of intercalated cells responded with a rapid intracellular acidification. The less frequent intercalated cell responded to basolateral $\mathrm{Cl}^{-}$ removal with intracellular alkalinization, consistent with the presence of basolateral $\mathrm{Cl}^{-} / \mathrm{HCO}_{3}^{-}$exchange. In view of the less frequent occurrence of these intercalated cells and their alka- linization in response to basolateral $\mathrm{Cl}^{-}$removal, they are functionally identified as $\alpha$-intercalated cells. Schwartz et al. (55) has recently described a third type of intercalated cell; these cells were infrequently found and appeared to have a basolateral $\mathrm{Cl}^{-} / \mathrm{HCO}_{3}^{-}$exchanger. In the present study these cells could have been identified as $\alpha$-intercalated cells.

Luminal $\mathrm{Cl}^{-} / \mathrm{HCO}_{3}^{-}$exchange was clearly present in $\beta$-intercalated cells. The $\mathrm{pH}_{\mathrm{i}}$ decrease with basolateral $\mathrm{Cl}^{-}$removal in the $\beta$-intercalated cell was completely dependent on the presence of luminal $\mathrm{Cl}^{-}$, suggesting that the removal of basolateral $\mathrm{Cl}^{-}$affected a luminal, $\mathrm{Cl}^{-}$dependent transporter. Basolateral $\mathrm{Cl}^{-}$removal probably induces intracellular $\mathrm{Cl}^{-}$exit via a basolateral $\mathrm{Cl}^{-}$channel $(3,35)$, thereby resulting in an increased lumen to cell $\mathrm{Cl}^{-}$gradient. The decrease in $\beta$-intercalated cell $\mathrm{pH}_{\mathrm{i}}$ with basolateral $\mathrm{Cl}^{-}$removal is therefore consistent with a luminal $\mathrm{Cl}^{-} / \mathrm{HCO}_{3}^{-}$exchanger transporting $\mathrm{Cl}^{-}$ from the lumen into the cell in exchange for $\mathrm{HCO}_{3}^{-}$. Similarly, the increase in $\mathrm{pH}_{\mathrm{i}}$ with luminal $\mathrm{Cl}^{-}$removal and the decrease in $\mathrm{pH}_{\mathrm{i}}$ with luminal $\mathrm{HCO}_{3}^{-}$removal are consistent with a luminal $\mathrm{Cl}^{-} / \mathrm{HCO}_{3}^{-}$exchanger. Inhibition of the fall in $\mathrm{pH}_{\mathrm{i}}$ in response to a decrease in luminal $\mathrm{HCO}_{3}^{-}$by removal of luminal $\mathrm{Cl}^{-}$shows that an apical $\mathrm{Cl}^{-} / \mathrm{HCO}_{3}^{-}$exchanger is present at the apical membrane of the $\beta$-intercalated cell. Studies by Schuster and Stokes have suggested the presence of a luminal transporter able to exchange $\mathrm{Cl}^{-}$for either $\mathrm{HCO}_{3}^{-}$or $\mathrm{Cl}^{-}(56)$; this transporter is stimulated by $\mathrm{CO}_{2} / \mathrm{HCO}_{3}^{-}$(57). CCT $\mathrm{HCO}_{3}^{-}$secretion appears to involve the coupled, 1:1 reabsorption of $\mathrm{Cl}^{-}$, suggestive of a luminal $\mathrm{Cl}^{-} / \mathrm{HCO}_{3}^{-}$exchanger being responsible for $\mathrm{HCO}_{3}^{-}$secretion (52). In summary, these results provide direct functional evidence for luminal $\mathrm{Cl}^{-}$/base exchange, most likely $\mathrm{Cl}^{-} / \mathrm{HCO}_{3}^{-}$exchange, in series with basolateral $\mathrm{Cl}^{-}$ transport in the $\beta$ intercalated cell type of the rabbit CCT.

An interesting finding in the $\beta$-intercalated cell is that no $\mathrm{pH}_{\mathrm{i}}$ recovery occurred during the intracellular acidosis associated with basolateral $\mathrm{Cl}^{-}$removal. Yet this was at a $\mathrm{pH}_{\mathrm{i}}$ at which $\mathrm{Na}^{+} / \mathrm{H}^{+}$exchange activity was clearly demonstrable after $\mathrm{NH}_{4}^{+}$pulse induced acidosis. Inhibition of $\mathrm{Na}^{+} / \mathrm{H}^{+}$exchange by amiloride during basolateral $\mathrm{Cl}^{-}$removal resulted in a reversible decrease in $\mathrm{pH}_{i}$, confirming that $\mathrm{Na}^{+} / \mathrm{H}^{+}$exchange is still active in the absence of basolateral $\mathrm{Cl}^{-}$. This suggests that $\mathrm{Na}^{+} / \mathrm{H}^{+}$exchange activity occurs, but that the maximal rate of $\mathrm{H}^{+}$extrusion is inadequate to return $\mathrm{pH}_{\mathrm{i}}$ to normal levels and that the luminal $\mathrm{Cl}^{-} / \mathrm{HCO}_{3}^{-}$exchanger has a large capacity for extruding $\mathrm{HCO}_{3}^{-}$, at least under certain conditions.

In summary, these studies provide the first direct examination of the $\mathrm{pH}_{\mathrm{i}}$ regulatory mechanisms of the various cell types of the heterogeneous rabbit CCT. Principal cells are shown to have both a basolateral $\mathrm{Na}^{+} / \mathrm{H}^{+}$exchanger and a previously unidentified basolateral $\mathrm{Cl}^{-} / \mathrm{HCO}_{3}^{-}$exchanger. The principal cell $\mathrm{Cl}^{-} / \mathrm{HCO}_{3}^{-}$exchanger is relatively inactive at baseline $\mathrm{pH}_{\mathrm{i}}$. Studies of single intercalated cells utilized basolateral $\mathrm{Cl}^{-}$removal to functionally separate $\alpha$ - and $\beta$-intercalated cells and allow their individual study. The $\alpha$-intercalated cell is functionally identified by intracellular alkalosis in response to peritubular $\mathrm{Cl}^{-}$removal; the $\beta$-intercalated cell by intracellular acidosis. In addition to direct functional evidence of $\beta$-intercalated cell luminal $\mathrm{Cl}^{-} / \mathrm{HCO}_{3}^{-}$exchange, a basolateral $\mathrm{Na}^{+} / \mathrm{H}^{+}$exchanger in the $\beta$-intercalated is demonstrated. Thus, both of these adjacent cell types have a basolateral $\mathrm{Na}^{+} / \mathrm{H}^{+}$exchanger. $\mathrm{Cl}^{-} / \mathrm{HCO}_{3}^{-}$exchange activity is found in 
all three cell types of the CCT, but the polarity of distribution and basal activity differs, suggesting different functions for the $\mathrm{Cl}^{-} / \mathrm{HCO}_{3}^{-}$exchangers in these neighboring cells.

\section{Acknowledgments}

The authors thank John Herndon for technical assistance during the performance of these studies. The continued support of Dr. Saulo $\mathrm{Klahr}$ is appreciated.

This work was supported by National Institute of Diabetes and Digestive and Kidney Diseases grants DK-07126, DK-09976, and DK-34394. Dr. Hamm is an Established Investigator of the American Heart Association.

\section{References}

1. Ridderstrale, Y., M. Kashgarian, B. Koeppen, G. Giebisch, D. Stetson, T. Ardito, and B. Stanton. 1988. Morphological heterogeneity of the rabbit collecting duct. Kidney Int. 34:655-670.

2. Madsen, K. M., and C. C. Tisher. 1986. Structural-functional relationships along the distal nephron. Am J Physiol. 250(Renal Fluid Electrolyte Physiol. 19):F1-F15.

3. Muto, S., G. Giebisch, and S. Sansom. 1987. Effects of adrenalectomy on CCD: evidence for differential response of two cell types. Am. J. Physiol. 253(Renal Fluid Electrolyte Physiol. 22):F742-F752.

4. O'Neil, R., and R. A. Hayhurst. 1985. Functional differentiation of cell types of cortical collecting duct. Am. J. Physiol. 248(Renal Fluid Electrolyte Physiol. 17):F449-F453.

5. Hamm, L. L., C. Gillespie, and S. Klahr. 1985. $\mathrm{NH}_{4} \mathrm{Cl}$ inhibition of transport in the rabbit cortical collecting tubule. Am. J. Physiol. 248(Renal Fluid Electrolyte Physiol. 17):F631-F637.

6. Molony, D. A., J. P. Kokko, D. Seldin, and H. R. Jacobson. 1984. Acid peritubular $\mathrm{pH}$ suppresses sodium reabsorption in cortical collecting tubules. Kidney Int. 25:279. (Abstr.)

7. Harvey, B. J., S. R. Thomas, and J. Ehrenfeld. 1988. Intracellular $\mathrm{pH}$ controls cell membrane $\mathrm{Na}^{+}$and $\mathrm{K}^{+}$conductances and transport in frog skin epithelium. J. Gen. Physiol. 92:767-791.

8. Palmer, L. G., and G. Frindt. 1987. Effects of cell $\mathrm{Ca}^{+2}$ and $\mathrm{pH}$ on Na channels from rat CCT. Am. J. Physiol. 253(Renal Fluid Electrolyte Physiol. 22):F333-F339.

9. Eaton, D. C., K. L. Hamilton, and K. E. Johnson. 1984. Intracellular acidosis blocks the basolateral $\mathrm{Na}-\mathrm{K}$ pump in rabbit urinary bladder. Am. J. Physiol. 247(Renal Fluid Electrolyte Physiol. 16):F946-F954.

10. Parisi, M., J. Wietzerbin, and J. Bourguet. 1983. Intracellular $\mathrm{pH}$, transepithelial $\mathrm{pH}$ gradients, and $\mathrm{ADH}$-induced water channels Am. J. Physiol. 244(Renal Fluid Electrolyte Physiol. 13):F712-F718.

11. Carvounis, C. P., S. D. Levine, and R. M. Hays. 1979. pH-dependence of water and solute transport in toad urinary bladder. Kidney Int. 15:513-519.

12. Lorenzen, M., A. Taylor, and E. E. Windhager. 1983. pH effect on osmotic response of collecting tubules to vasopressin and 8-CPTcAMP. Am. J. Physiol. 245(Renal Fluid Electrolyte Physiol. 14):F188-F197.

13. Brem, A. S., M. Pacholski, and R. G. Lawler. 1986. Fluctuation in intracellular $\mathrm{pH}$ associated with vasopressin stimulation. Am. J. Physiol. 251(Renal Fluid Electrolyte Physiol. 20):F897-F903.

14. Ganz, M. B., G. Boyarsky, R. B. Sterzel, and W. F. Boron. 1989. Arginine vasopressin enhances $\mathrm{pH}_{\mathrm{i}}$ regulation in the presence of $\mathrm{HCO}_{3}^{-}$by stimulating 3 acid-base transport-systems. Nature (Lond.). 337:648-651.

15. Grinstein, S., and A. Rothstein. 1986. Mechanisms of regulation of the $\mathrm{Na}^{+} / \mathrm{H}^{+}$exchanger. J. Membr. Biol. 90:1-12.

16. Parisi, M., and J. Wietzerbin. 1984. Cellular pH and the ADH- induced hydroosmotic response in different ADH target epithelia. Pfluegers Arch. Eur. J. Physiol. 402:211-215.

17. Paillard, M., and M. Bichara. Peptide hormone effects on urinary acidification and acid-base balance: PTH, ADH, and glucagon. Am. J. Physiol. 256(Renal Fluid Electrolyte Physiol. 25):F973-F985.

18. McKinney, T. D., and M. B. Burg. 1978. Bicarbonate secretion by rabbit cortical collecting tubules in vitro. J. Clin. Invest. 61:14211427.

19. McKinney, T. D., and M. B. Burg. 1978. Bicarbonate absorption by rabbit cortical collecting tubules in vitro. Am. J. Physiol. 234(Renal Fluid Electrolyte Physiol. 3):F141-F145.

20. Brown, D., S. Hirsch, and S. Gluck. 1988. Localization of a proton-pumping ATPase in rat kidney. J. Clin. Invest. 82:2114-2126.

21. Schuster, V. L. 1985. Cyclic adenosine monophosphate-stimulated bicarbonate secretion in the rabbit cortical collecting tubule. $J$. Clin. Invest. 74:2056-2064.

22. Verlander, J. W., K. M. Madsen, P. S. Low, D. P. Allen, and C. C. Tisher. 1988. Immunocytochemical localization of band 3 protein in the rat collecting duct. Am. J. Physiol. 255(Renal Fluid Electrolyte Physiol. 24):F115-F125.

23. Schuster, V. L., S. M. Bonsib, and M. L. Jennings. 1986. Two types of collecting duct mitochondria-rich (intercalated) cells: lectin and band 3 cytochemistry. Am. J. Physiol. 251(Cell Physiology. 20):C347-C355.

24. Tago, K., V. L. Schuster, and J. B. Stokes. 1986. Regulation of $\mathrm{Cl}^{-}$self-exchange by cAMP in cortical collecting tubule. Am. J. Physiol. 251(Renal Fluid Electrolyte Physiol. 20):F40-F48.

25. Weiner, I. D., and L. L. Hamm. 1989. Use of fluorescent dye BCECF to measure intracellular $\mathrm{pH}$ in cortical collecting tubule. $\mathrm{Am}$. J. Physiol. 256(Renal Fluid Electrolyte Physiol. 25):F957-F964.

26. Burg, M. B., J. Grantham, M. Abramow, and J. Orloff. 1966. Preparation and study of fragments of single rabbit nephrons. Am. J. Physiol. 210:1293-1298.

27. Thomas, J. A., R. N. Buchsbaum, A. Fimniak, and S. Racker. 1979. Intracellular pH measurements in Ehrlich ascites tumor cells utilizing spectroscopic probes generated in situ. Biochem. J. 18:2210 2218.

28. Reinertsen, K. V., T. I. Tonnessen, J. Jacobsen, K. Sandvig, and S. Olsnes. 1988. Role of chloride/bicarbonate antiport in the control of cytosolic pH: cell-line differences in activity and regulation of antiport. J. Biol. Chem. 263:11117-11125.

29. Beck, F.-X., A. Dörge, R. Rick, M. Schramm, and K. Thurau. 1988. The distribution of potassium, sodium and chloride across the apical membrane of renal tubular cells: effect of acute metabolic alkalosis. Pfluegers Arch. Eur. J. Physiol. 411:259-267.

30. Gifford, D., R. Rick, R. G. Luke, and J. H. Galla. 1989. Intracellular $\mathrm{Na}^{+}, \mathrm{K}^{+}$, and $\mathrm{Cl}^{-}$concentration in the rat cortical collecting duct during chloride depletion alkalosis. Clin. Res. 37:490a. (Abstr.)

31. Sansom, S. C., E. J. Weinman, and R. G. O'Neil. 1984. Microelectrode assessment of chloride-conductive properties of cortical collecting duct. Am. J. Physiol. 247(Renal Fluid Electrolyte Physiol. 16):F291-F302.

32. Schwartz, G. J., J. Barasch, and Q. Al-Awqati. 1985. Plasticity of functional epithelial polarity. Nature (Lond.). 318:368-371.

33. Strange, K. 1989. Ouabain-induced cell swelling in rabbit cortical collecting tubule: $\mathrm{NaCl}$ transport by principal cells. J. Membr. Biol. 107:249-261.

34. Matsuzaki, K., J. B. Stokes, and V. L. Schuster. 1989. Stimulation of $\mathrm{Cl}^{-}$self exchange by intracellular $\mathrm{HCO}_{3}^{-}$in rabbit cortical collecting duct. Am. J. Physiol. 257(Cell Physiol. 26):C94-C101.

35. Tago, K., D. H. Warden, V. L. Schuster, and J. B. Stokes. 1986. Effects of inhibitors of $\mathrm{Cl}$ conductance on $\mathrm{Cl}$ self-exchange in rabbit cortical collecting tubule. Am. J. Physiol. 251(Renal Fluid Electrolyte Physiol. 20):F1009-F1017.

36. Kleyman, T. R., and E. J. Cragoe. 1988. Amiloride and its analogs as tools in the study of ion transport. J. Membr. Biol. 105:121. 
37. Alpern, R. J. 1985. Mechanism of basolateral membrane $\mathrm{H}^{+} / \mathrm{OH}^{-} / \mathrm{HCO}_{3}^{-}$transport in the rat proximal convoluted tubule: a sodium coupled process. J. Gen. Physiol. 86:613-636.

38. Lopes, A. G., A. W. Siebens, G. Giebisch, and W. F. Boron. 1987. Electrogenic $\mathrm{Na} / \mathrm{HCO}_{3}$ cotransport across basolateral membrane of isolated perfused Nectarus proximal tubule. Am. J. Physiol. 253(Renal Fluid Electrolyte Physiol. 22):F340-F350.

39. Sasaki, S., and N. Yoshiyama. 1988. Interaction of chloride and bicarbonate transport across the basolateral membrane of rabbit proximal straight tubule. Evidence for sodium coupled chloride/bicarbonate exchange. J. Clin. Invest. 81:1004-1011.

40. Moolenaar, W. H. 1986. Regulation of cytoplasmic pH by $\mathrm{Na}^{+} / \mathrm{H}^{+}$exchange. TIBS 11:141-143.

41. Grinstein, S., and A. Rothstein. 1986. Mechanisms of regulation of the $\mathrm{Na}^{+} / \mathrm{H}^{+}$exchanger. J. Membr. Biol. 90:1-12.

42. Grinstein, S., J. D. Goetz, S. Cohen, W. Furuya, A. Rothstein, and $E$. W. Gelfand. 1985. Mechanism of regulatory volume increase in osmotically shrunken lymphocytes. Mol. Physiol. 8:185-197.

43. Preisig, P. A., and F. C. Rector. 1988. Role of $\mathrm{Na}^{+}-\mathrm{H}^{+}$antiport in rat proximal tubule $\mathrm{NaCl}$ absorption. Am. J. Physiol. 255(Renal Fluid Electrolyte Physiol. 24):F461-F465.

44. Chaillet, J. R., A. G. Lopes, and W. F. Boron. 1985. Basolateral $\mathrm{Na}-\mathrm{H}$ exchange in the rabbit cortical collecting tubule. J. Gen. Physiol. 86:795-812.

45. Breyer, M. D., and H. R. Jacobson. 1989. Functional evidence for parallel basolateral $\mathrm{Na}^{+} / \mathrm{H}^{+}$and $\mathrm{Cl}^{-} / \mathrm{HCO}_{3}^{-}$exchangers in the inner stripe, outer medullary collecting duct $\left(\mathrm{OMCD}_{\mathrm{i}}\right)$ of rabbit. Kidney Int. 35:451. (Abstr.)

46. Hays, S., and R. Alpern. 1989. Response of the inner stripe of the outer medullary collecting tubule $\left(\mathrm{OM}_{\mathrm{i}} \mathrm{CT}\right)$ to acid loads. Clin. Res. 37:491 $a$. (Abstr.)

47. Wall, S. M., S. Muallem, and J. A. Kraut. 1987. Detection of a $\mathrm{Na}^{+} / \mathrm{H}^{+}$antiporter in cultured rat renal papillary collecting duct cells. Am. J. Physiol. 253(Renal Fluid Electrolyte Physiol. 22):F889-F895.
48. Kleinman, J. G., S. S. Blumenthal, J. H. Wiessner, K. L. Reetz, D. L. Lewand, N. S. Mandel, G. S. Mandel, J. C. Garancis, and E. J. Cragoe, Jr. 1987. Regulation of $\mathrm{pH}$ in rat papillary tubule cells in primary culture. J. Clin. Invest. 80:1660-1669.

49. Gluck, S., C. Cannon, and Q. Al-Awqati. 1982. Exocytosis regulates $\mathrm{H}^{+}$transport in the turtle bladder by rapid insertion of $\mathrm{H}^{+}$ pumps into the luminal membrane. Proc. Natl. Acad. Sci. USA. 79:4327-4331.

50. Schwartz, G. J., and Q. Al-Awqati. 1985. $\mathrm{CO}_{2}$ causes exocytosis of vesicles containing $\mathrm{H}^{+}$pumps in isolated perfused proximal and collecting tubules. J. Clin. Invest. 75:1638-1644.

51. Schwartz, G. J., and Q. Al-Awqati. 1986. Regulation of transepithelial $\mathrm{H}^{+}$transport by exocytosis and endocytosis. Annu. Rev. Physiol. 48:153-161.

52. Star, R. A., M. B. Burg, and M. A. Knepper. 1985. Bicarbonate secretion and chloride absorption by rabbit cortical collecting ducts: role of chloride/bicarbonate exchange. J. Clin. Invest. 76:1123-1130.

53. Arruda, J. A. L., G. Dytko, R. Mola, and N. A. Kurtzman. 1980. On the mechanism of lithium-induced renal tubular acidosis: studies in the turtle bladder. Kidney Int. 17:196-204.

54. Kurtz, I., and K. Golchini. 1987. $\mathrm{Na}^{+}$-independent $\mathrm{Cl}^{-}-\mathrm{HCO}_{3}^{-}$ exchange in madin-darby canine kidney cells: role in intracellular $\mathrm{pH}$ regulation. J. Biol. Chem. 262:4516-4520.

55. Schwartz, G. J., L. M. Satlin, and J. E. Gergmann. 1988. Fluorescent characterization of collecting duct cells: a second $\mathrm{H}^{+}$-secreting type. Am. J. Physiol. 255(Renal Fluid Electrolyte Physiol. 24):F1003F1014.

56. Schuster, V. L., and J. B. Stokes. 1987. $\mathrm{Cl}^{-}$transport by the cortical and outer medullary collecting duct. Am. J. Physiol. 253(Renal Fluid Electrolyte Physiol. 22):F203-F212.

57. Tago, K., V. L. Schuster, and J. B. Stokes. 1986. Stimulation of chloride transport by $\mathrm{HCO}_{3}^{-}-\mathrm{CO}_{2}$ in rabbit cortical collecting tubule. Am. J. Physiol. 251(Renal Fluid Electrolyte Physiol. 20):F49-F56. 